\title{
Zeranol stimulates proliferation and aromatase activation in human breast preadipocytes
}

\author{
SAIYI ZHONG ${ }^{1}$, SHOUCHUN LIU ${ }^{2}$, SUHUA CHEN ${ }^{1}$, HUAJUAN LIN $^{1}$, WEIMIN WANG $^{1}$ and XIAOMING QIN ${ }^{1}$ \\ ${ }^{1}$ Department of Food Science, College of Food Science and Technology, Guangdong Ocean University, Zhanjiang, \\ Guangdong 524088; ${ }^{2}$ Beijing Academy of Agriculture and Forestry Science, Beijing 100097, P.R. China
}

Received May 28, 2015; Accepted April 18, 2016

DOI: $10.3892 / \mathrm{mmr} .2016 .5293$

\begin{abstract}
Aromatase is a crucial enzyme for the biosynthesis of estrogens and is involved in the process of breast carcinogenesis. Concerns have been raised regarding the effects of environmental estrogens as potential regulators of aromatase expression in human breast cells. Zeranol is a non-steroidal agent with potent estrogenic activity, which is widely used as a growth promoter for cattle in certain countries. The present study hypothesized that aromatase expression and activity may be elevated by low dose zeranol exposure, providing a source of estrogens that may stimulate cell proliferation. In the present study, primary cultured human breast preadipocytes were used as an in vitro model. The effects of zeranol on cell proliferation were measured using the MTS assay, aromatase expression levels were determined by immunocytochemical staining and reverse transcription-polymerase chain reaction, and aromatase enzyme activity and estrogen production were analyzed using corresponding assay kits. The results demonstrated that low dose zeranol (2-50 nM) was able to significantly promote cell proliferation, aromatase mRNA expression, aromatase activity and estrogen production in primary cultured human breast preadipocytes, thus suggesting that zeranol may act as an aromatase activator. The findings of the present study suggest that zeranol promotes breast cancer cell growth by stimulating aromatase activation and increasing estrogen biosynthesis in adipose tissue.
\end{abstract}

\section{Introduction}

Breast cancer is currently the most common cancer among women in the United States (US), and is the second leading cause of cancer-associated mortality in women worldwide (1).

Correspondence to: Dr Xiaoming Qin, Department of Food Science, College of Food Science and Technology, Guangdong Ocean University, 1 Haida Road, Zhanjiang, Guangdong 524088, P.R. China

E-mail: 284761959@qq.com

Key words: zeranol, proliferation, aromatase activation, human breast preadipocytes
One of the potential factors that contributes to breast carcinogenesis is the increased exposure of epithelial cells to estrogens produced locally by the tissue microenvironment (2). It is clear that estrogens increase mammary gland cell proliferation, predominantly via estrogen receptor (ER)-mediated mechanisms in estrogen-dependent breast tumors $(3,4)$. The synthesis of estrogens in breast tissue is catalyzed by the enzyme aromatase, which is encoded by the gene cytochrome P450 family 19 subfamily A member 1 (CYP19A1). Aromatase is a cytochrome $\mathrm{P} 450$, which synthesizes estrogens by converting $\mathrm{C} 19$ androgens to aromatic $\mathrm{C} 18$ estrogenic steroids, thus catalyzing the rate-limiting or final step of estrogen synthesis $(5,6)$.

Estrogen, and various growth factors in the breast adipose microenvironment that affect tumor behavior, are increasingly been recognized. Although the major site of estrogen production is reproductive tissue, peripheral estrogen synthesis in adipose or fat tissue is thought to be a major source of estrogen in postmenopausal women (7). Estrogen production in adipose tissue has previously been demonstrated to provide excessive estrogen for the stimulation and progression of postmenopausal breast cancer cells, and elevated enzymatic activity of aromatase has been detected in the adjacent adipose stroma of breast carcinoma $(8,9)$. Preadipocytes and adipocytes are major cell types present in the breast adipose tissue microenvironment (10). Cancer-associated adipocytes exhibit an activated phenotype and contribute to breast cancer invasion (11). Long-term exposure to estrogens and non-estrogenic agents with estrogenic actions, such as endocrine disruptors, may be important in human breast carcinogenesis. Previous studies have reported that some endocrine disruptors may interact with in situ steroidogenesis by altering tissue components, such as increased aromatase expression, in certain tissues $(12,13)$.

Zeranol is a non-steroidal estrogen agonist that is approved for use as a growth promoter in livestock, including beef cattle, in various countries. However, previous studies have suggested that it may not be as safe as previously demonstrated $(14,15)$. Exposure to hormonal growth promoters or endocrine disruptors elevates the probability of histological alterations in human mammary epithelial cells, which may lead to the growth of pre-neoplastic cells (16). A previous report demonstrated that zeranol is comparable to natural $17 \beta$-estradiol (E2) and the synthetic estrogen diethylstilbestrol in its ability to transform MCF-10A normal human breast epithelial cells to a pre-cancerous phenotype in vitro (17). A follow-up study demonstrated that implantation 
of zeranol in beef heifers was able to greatly enhance the proliferation of preadipocytes by elevating cyclin D1 and reducing P53 gene expression (18). Furthermore, a previous study suggested that zeranol may increase estrogen production in breast adipose tissues, which in turn may increase the proliferation of normal human breast epithelial cells (19).

The long-term goal of the present study is to investigate the effects of zeranol residues in beef and their potential adverse effects on human breast health. The present study hypothesized that aromatase expression and activity may be elevated in response to low dose zeranol exposure, providing a source of estrogens, which may promote the proliferation of carcinoma clones derived from breast cells. The aim of the present study was to investigate this hypothesis and to improve understanding regarding the effects of zeranol on breast carcinogenesis.

\section{Materials and methods}

Cell culture. Human breast preadipocytes were isolated from normal adipose tissue during breast reduction surgery (36-year-old female) by collagenase and hyaluronidase digestion, and cultured as previously described (19). Preconfluent human breast preadipocytes were repeatedly subcultured in Dulbecco's modified Eagle's medium (DMEM)/F12 medium supplemented with $5 \%$ fetal bovine serum (FBS), $100 \mathrm{U} / \mathrm{ml}$ penicillin sodium, $100 \mu \mathrm{g} / \mathrm{ml}$ streptomycin sulfate and $0.25 \mu \mathrm{g} / \mathrm{ml}$ amphotericin $\mathrm{B}$ at $37^{\circ} \mathrm{C}$ (all from Gibco; Thermo Fisher Scientific, Inc., Waltham, MA, USA). All experiments were conducted on primary cultured preadipocytes up to passage 4 . The study was approved by the ethics committee of Guangdong Ocean University (Zhanjiang, China) and written informed consent was obtained from the patient.

Cell proliferation assay. Primary cultured human breast preadipocytes were cultured in $100 \mu \mathrm{l}$ DMEM/F12 medium in 96-well culture plates at an initial density of $4 \times 10^{3}$ viable cells/well. Following an overnight culture, the medium was replaced with DMEM/F12 supplemented with $0.2 \%$ bovine serum albumin (BSA; Sigma-Aldrich, St. Louis, MO, USA) and cultured overnight. The experimental cells were treated with various doses (0, 2 and $50 \mathrm{nM})$ of zeranol (Sigma-Aldrich), and $50 \mathrm{nM}$ zeranol plus 100 nM ICI 182,780 (Sigma-Aldrich), whereas the control group was treated with $0.1 \%$ dimethyl sulfoxide at $37^{\circ} \mathrm{C}$ for $48 \mathrm{~h}$. Subsequently, cell growth was observed by measuring the optical density at $490 \mathrm{~nm}$ according to the manufacturer's protocol. Briefly, 3-(4,5-dimethylthiazol-2-yl)-5-(3-carboxymethoxyphen yl)-2-(4-sulfophenyl)-2-H-tetrazolium (MTS) was mixed with phenazine methosulfate (Promega Corporation, Madison WI, USA), and $20 \mu \mathrm{l}$ was added to each well and incubated for $2 \mathrm{~h}$ at room temperature. The color density was determined at $490 \mathrm{~nm}$ using a kinetic microplate reader (UV-max; Molecular Devices, LLC, Sunnyvale, CA, USA), and cell growth was compared.

Immunocytochemical staining. The cells were grown on slides overnight, and were then fixed with $4 \%$ paraformaldehyde at room temperature for $10 \mathrm{~min}$, washed in $10 \mathrm{mM}$ phosphate-buffered $150 \mathrm{mM}$ saline (PBS, $\mathrm{pH}$ 7.4) with $0.1 \%$ Triton X-100 (Sigma-Aldrich) for $10 \mathrm{~min}$, and blocked in 10\% normal donkey serum (Sigma-Aldrich) in $0.1 \%$ BSA in PBS for $60 \mathrm{~min}$. The slides were incubated with monoclonal mouse anti-human aromatase antibody (MCA2077S; AbD Serotec, Raleigh, NC, USA; 1:50 dilution in 3\% BSA) overnight at $4^{\circ} \mathrm{C}$. Subsequently, the slides were incubated with goat anti-mouse Texas Red-labeled antibody (sc-2781; Santa Cruz Biotechnology, Inc., Dallas, TX, USA; 1:200 dilution in PBS) for $45 \mathrm{~min}$ at room temperature. Prior to mounting, the nuclei were stained for $5 \mathrm{~min}$ with $5 \mu \mathrm{g} / \mathrm{ml}$ 4,6-diamidino-2-phenylindole (DAPI; Vector Laboratories, Inc., Burlingame, CA, USA), and were then observed under an Olympus compound microscope (BX51; Olympus Corporation, Tokyo, Japan) equipped with a Nikon digital camera (E8400; Nikon Corporation, Tokyo, Japan).

Aromatase activity assay. Preadipocytes were cultured for 24 and $48 \mathrm{~h}$ in DMEM/F12 medium with or without various doses $(0,2$ and $50 \mathrm{nM})$ of zeranol and $50 \mathrm{nM}$ zeranol plus $1 \mu \mathrm{M}$ letrozole (Sigma-Aldrich). The aromatase activity in the culture medium was examined by tritiated water release assay using $[1 \beta-3 \mathrm{H}]$ androst-4-ene-3,17-dione $(0.5 \mu \mathrm{M}$; Sigma-Aldrich) as a substrate, as previously described (20). The cells were incubated at $37^{\circ} \mathrm{C}$ for $5 \mathrm{~h}$ in an air/ $\mathrm{CO}_{2}(5 \%)$ atmosphere. The data were expressed as fmol/h and normalized to $\mathrm{mg}$ of protein (fmol/h/mg protein).

Cell treatment and total RNA extraction. All experiments were carried out on cells that exhibited $>95 \%$ viability, as measured using the trypan blue dye exclusion method (21). Preadipocytes were seeded in 6-well plates at $1 \times 10^{5}$ cells/well in high-calcium DMEM/F12 containing 10\% Chelex-100 (Bio-Rad Laboratories, Inc., Hercules, CA, USA)-treated FBS. Following an overnight culture, the medium was replaced with phenol red-free high-calcium DMEM/F12 containing 5\% dextran-coated charcoal (DCC; Sigma-Aldrich)-stripped Chelex-100-treated FBS. After $24 \mathrm{~h}$, the cells were treated with zeranol (2, 10 and $50 \mathrm{nM}$ ), and the control cells were treated with the vehicle, in phenol-red-free high-calcium DMEM/F12 supplemented with $5 \%$ DCC-treated FBS for $24 \mathrm{~h}$ at $37^{\circ} \mathrm{C}$. Total RNA was extracted using TRIzol ${ }^{\circledR}$ reagent (Invitrogen; Thermo Fisher Scientific, Inc.) according to the manufacturer's protocol.

cDNA synthesis. cDNA synthesis was performed as described previously (19). Briefly, $1 \mu \mathrm{g}$ total RNA from the cultured cells was reverse transcribed with 200 U M-MLV Reverse Transcriptase (Invitrogen; Thermo Fisher Scientific, Inc.) at $37^{\circ} \mathrm{C}$ for $50 \mathrm{~min}$, in the presence of $1 \mu 110 \mathrm{mM}$ dNTP mix (dATP, dCTP, dGTP and dTTP), $10 \mu \mathrm{l}$ 5X first-strand buffer, $5 \mu 10.1$ M DDT, $1 \mu 1$ RNAase inhibitor (all from Invitrogen; Thermo Fisher Scientific, Inc.) and $1 \mu \mathrm{M}$ random hexamers in a total volume of $50 \mu \mathrm{l}$. The reaction was terminated by heating to $95^{\circ} \mathrm{C}$ for $5 \mathrm{~min}$. Reactions were carried out using the Eppendorf Mastercycler gradient (Eppendorf, Hamburg, Germany). RNA concentration was measured using a DU-70 spectrophotometer (Beckman Coulter, Inc., Brea, CA, USA).

Reverse transcription-polymerase chain reaction (RT-PCR). The newly synthesized cDNA was used as a template for PCR. cDNA $(2 \mu \mathrm{l})$ was mixed with $1.25 \mu 1 \mathrm{MgCl}_{2}(50 \mathrm{mM}), 2.5 \mu \mathrm{l} 10 \mathrm{X}$ PCR buffer II, $0.2 \mu 1 \mathrm{Taq}$ polymerase ( $5 \mathrm{U} / \mu \mathrm{l}$ ), and $0.3 \mu \mathrm{l}$ sense and antisense primers (all from Gibco; Thermo Fisher Scientific, Inc.) in a total volume of $25 \mu$ l. One pair of primers was for the amplification of human CYP19A1 and the other was for 


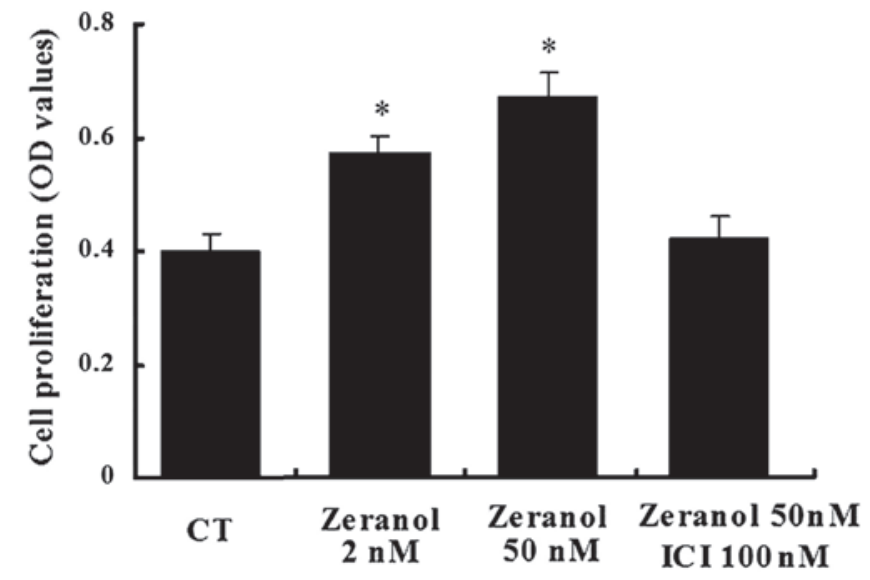

Figure 1. Effects of zeranol on proliferation of human breast preadipocytes. Cells were incubated with various concentrations of zeranol, or were co-incubated with $100 \mathrm{nM}$ ICI for $48 \mathrm{~h}$. Dimethyl sulfoxide $(0.1 \%)$ was used as a control. Data are presented as the mean \pm standard deviation $(n=3)$. ${ }^{*} \mathrm{P}<0.05$ vs. CT. OD, optical density; CT, control; ICI, ICI 182,780.

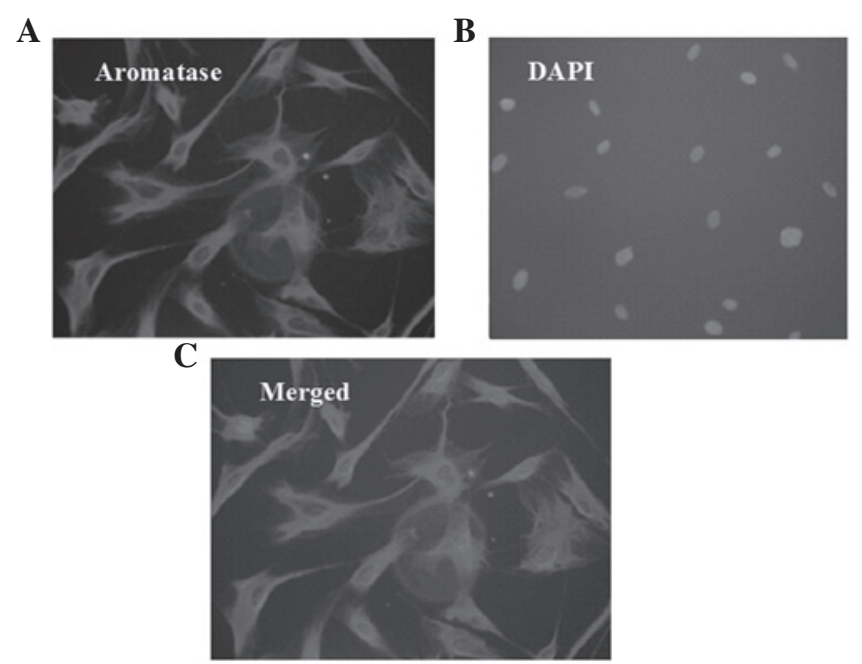

Figure 2. Aromatase protein expression in primary cultured human breast preadipocytes, as detected by immunocytochemistry. (A) Aromatase was widely expressed in the cytoplasm only. (B) Nuclei were stained with DAPI. (C) Merged aromatase and DAPI fluorescence. Magnification, x430. DAPI, 4,6-diamidino-2-phenylindole.

human ribosomal protein lateral stalk subunit P0 (36B4), which was used as a positive and loading control. PCR for CYP19A1 was conducted using the T100 Thermal Cycler (Bio-Rad Laboratories, Inc.) under the following cycling conditions: Initial denaturation at $94^{\circ} \mathrm{C}$ for $3 \mathrm{~min}, 36$ cycles of $94^{\circ} \mathrm{C}$ for $45 \mathrm{sec}, 60^{\circ} \mathrm{C}$ for $45 \mathrm{sec}$ and $72^{\circ} \mathrm{C}$ for $60 \mathrm{sec}$, final extension step of $72^{\circ} \mathrm{C}$ for $4 \mathrm{~min}$. The primer sequences used were as follows: CYP19A1, sense 5'-CCTGGCTACTGCATGGGAAT-3', antisense 3'-GCC TTTCTCATGCATACCGA-5', product size $246 \mathrm{bp}$; and 36B4, sense 5'-AGCTGATCAAGACTGGAGACAAA-3', antisense 3'-GGGTAGCCA ATCTGCAGACA-5', product size $220 \mathrm{bp}$. The final RT-PCR products $(10 \mu \mathrm{l})$ were run on a $1.5 \%$ agarose gel containing ethidium bromide (Bio-Rad Laboratories, Inc.). The 100 bp DNA ladder (Promega Corporation) was used as marker. The specific bands were semi-quantified by Fujifilm MultiGauge software, version 3.0 (Fuji Life Sciences,
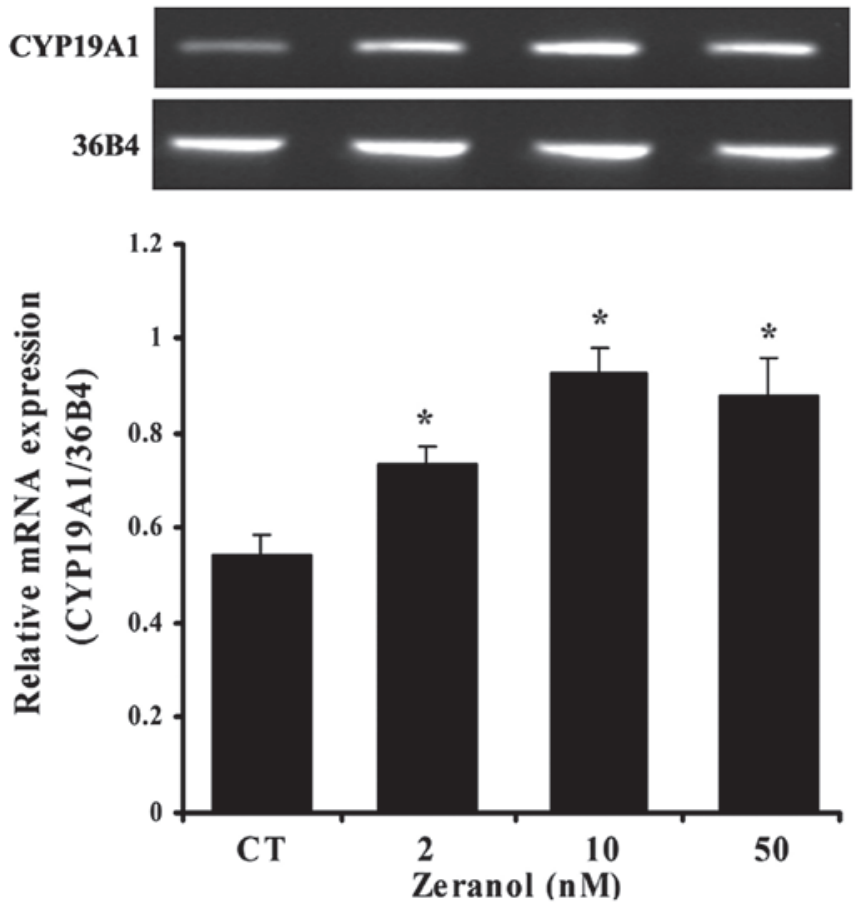

Figure 3. Effects of zeranol on aromatase mRNA expression in primary cultured human breast preadipocytes. Cells were treated with 2, 10 or $50 \mathrm{nM}$ zeranol for $48 \mathrm{~h}$. The CT group was treated with dimethyl sulfoxide $(0.1 \%)$. The upper panel is a representative image of gel electrophoresis following reverse transcription-polymerase chain reaction. In the lower panel, each bar represents the mean \pm standard deviation of three experiments semi-quantified by MultiGauge software. ${ }^{*} \mathrm{P}<0.05$ vs. CT. CT, control; CYP19A1, aromatase; 36B4, ribosomal protein lateral stalk subunit $\mathrm{P} 0$.

Stamford, CT, USA). The results are presented as the ratio of CYP19A1 to 36B4.

E2 production assay. Cells were seeded in 6-well plates at $1 \times 10^{5}$ cells/well in $5 \mathrm{ml}$ high-calcium DMEM/F12 containing $10 \% \mathrm{FBS}$, and were cultured overnight at $37^{\circ} \mathrm{C}$. The medium was replaced with DMEM/F12 supplemented with 5\% DCC-treated FBS for a further $24 \mathrm{~h}$, and the preadipocytes were then treated with the indicated doses of zeranol (2, 10 and $30 \mathrm{nM})$ for $48 \mathrm{~h}$. Following treatment, $200 \mu \mathrm{l}$ culture medium was collected, and the levels of E2 in the culture medium were determined using an enzyme-linked immunosorbent assay (ELISA) kit (ALPCO, Salam, NH, USA). The kit was specific for E2 and did not cross-react with estriol or estrone.

Statistical analysis. Statistical analysis was performed using Minitab 15 (Minitab Inc., State College, PA, USA). Differences between groups were evaluated by one-way analysis of variance, followed by Dunnett's test for multiple comparisons. $\mathrm{P}<0.05$ was considered to indicate a statistically significant difference.

\section{Results}

Zeranol promotes the proliferation of preadipocytes. Following $48 \mathrm{~h}$ of treatment, zeranol increased the proliferation of preadipocytes in a dose-dependent manner, as determined by an MTS assay (Fig. 1). Compared with the control cells, treatment with 2 and $50 \mathrm{nM}$ zeranol increased the proliferation of preadipocytes by 30 and $41 \%(\mathrm{P}=0.036$ and 0.023 , respectively). Treatment with 


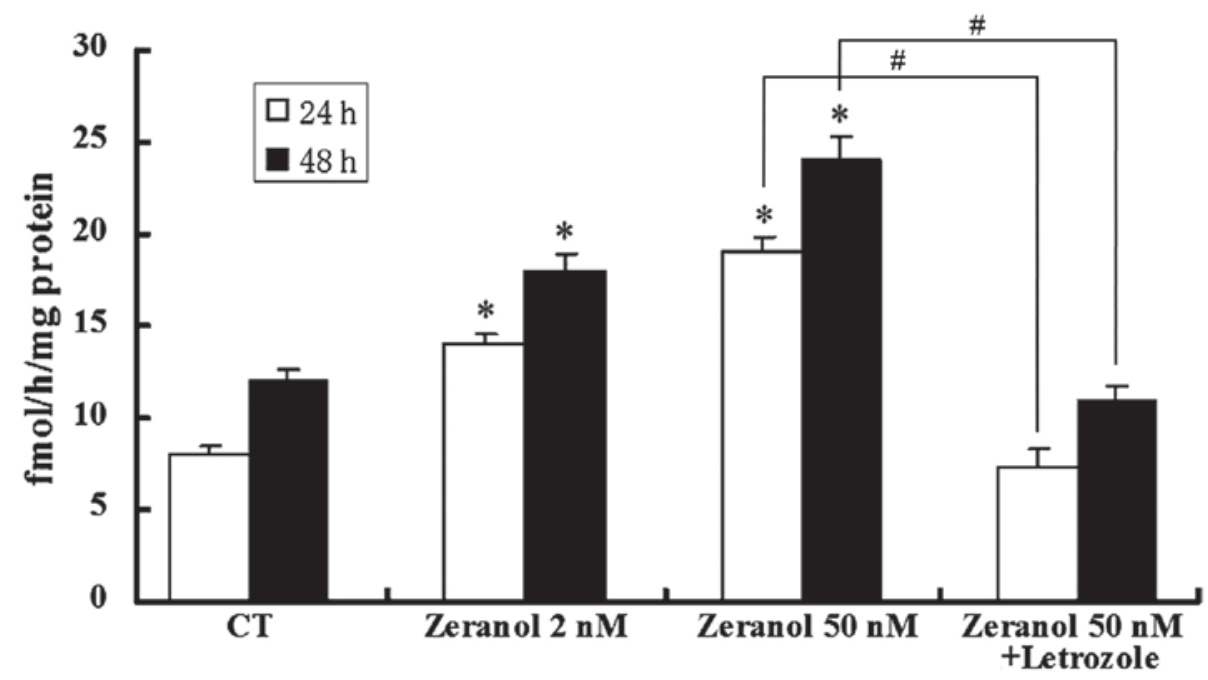

Figure 4. Effects of zeranol on aromatase activity in primary cultured human breast preadipocytes. Cells were cultured for 24 and 48 h in the absence or presence of 2 and $50 \mathrm{nM}$ zeranol. Cells were also treated with the aromatase inhibitor letrozole $(1 \mu \mathrm{M})$. Data are presented as a the mean \pm standard deviation (n=3). ${ }^{*} \mathrm{P}<0.05$ vs. $\mathrm{CT}$; ${ }^{\#} \mathrm{P}<0.05$ as indicated by brackets. $\mathrm{CT}$, control.

the ER antagonist, ICI 182,780 (ICI) abrogated zeranol-induced proliferation. These results suggest that zeranol may promote cell proliferation via an effect on ER.

Aromatase-positive staining is observed in the cytoplasm of preadipocytes. Positive aromatase immunofluorescent staining was observed in $>80 \%$ of cells in a random field, whereas DAPI staining was only observed in the nucleus (Fig. 2).

Zeranol enhances aromatase $m R N A$ expression in preadipocytes. The effects of zeranol on the mRNA expression levels of aromatase in human breast preadipocytes were investigated by RT-PCR. The results demonstrated that treatment with 2, 10 and $50 \mathrm{nM}$ zeranol for $48 \mathrm{~h}$ induced a significant increase in the mRNA expression levels of aromatase compared with the control $(\mathrm{P}=0.039,0.022$ and 0.028 , respectively; Fig. 3$)$. The reference gene $36 \mathrm{~B} 4$ was used for normalization.

Stimulation of aromatase activity by zeranol in preadipocytes. Preadipocytes were incubated in the presence of various concentrations of zeranol (2 and $50 \mathrm{nM}$ ) for 24 and $48 \mathrm{~h}$. Subsequently, the aromatase activity was measured by tritiated water assay. As demonstrated in Fig. 4, low doses of zeranol (2 and $50 \mathrm{nM}$ ) significantly increased the enzymatic activity of aromatase in preadipocytes compared with the control cells, following treatment for 24 and $48 \mathrm{~h}(\mathrm{P}=0.031$ and 0.033 , respectively). However, the promotion of aromatase activity was completely reversed by co-treatment with the aromatase inhibitor, letrozole $(\mathrm{P}=0.025$ and 0.023 , respectively).

Zeranol significantly increases E2 production. To determine whether the increase in aromatase gene expression and activity resulted in increased E2 levels, the levels of E2 were detected in the medium of preadipocytes treated with 2, 10 and $30 \mathrm{nM}$ zeranol for $48 \mathrm{~h}$ using a commercially available ELISA kit. E2 concentrations were significantly increased in the medium of zeranol-treated cells, as compared with in the control cells in a dose-dependent manner $(\mathrm{P}=0.037,0.026$ and 0.024 , respectively; Fig. 5).

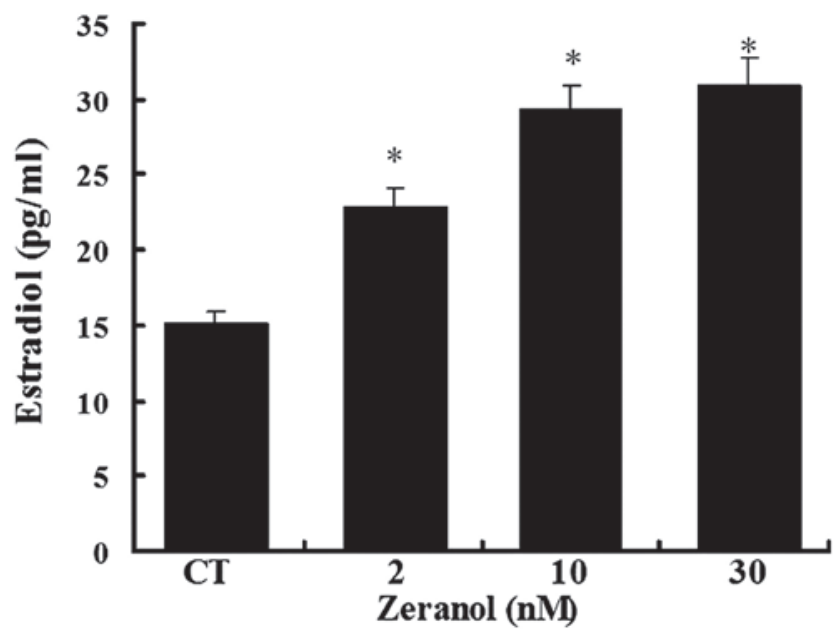

Figure 5. Effects of zeranol on estradiol production in primary cultured human breast preadipocytes. Cells were treated with various doses of zeranol for $48 \mathrm{~h}$. Data are presented as the mean \pm standard deviation $(\mathrm{n}=3){ }^{*} \mathrm{P}<0.05$ vs. CT. CT, control.

\section{Discussion}

Cumulative exposure to estrogen is known to be a risk factor for the development and mitogenic stimulation of breast cancer (22). The cytochrome P450 enzyme complex, termed aromatase, catalyzes the formation of estrogens from $\mathrm{C} 19$ androgens to aromatic $\mathrm{C} 18$ estrogen through three consecutive hydroxylation reaction steps. Since estrogen is involved in the development of breast cancer and aromatase is the final enzyme responsible for estrogen production, high aromatase expression in breast cancer cells may affect breast cancer progression and maintenance (23). It has previously been demonstrated that aromatase is expressed in breast cancer tissue, and is at a higher level compared with in non-cancerous breast tissue (24). Previous studies have demonstrated that aromatase activity in malignant or surrounding tissues may promote tumor growth by local estrogen generation $(25,26)$. Furthermore, previous reports have demonstrated that some 
endocrine disruptors may increase estrogen production and aromatase activity (27-29).

Zeranol, which is a nonsteroidal agent with potent estrogenic activity, is used in the US beef industry as an anabolic growth promoter. Bioactive zeranol and its metabolites present in the meat of zeranol-implanted beef cattle may be considered an endocrine disruptor for human consumers. It has previously been demonstrated that zeranol enhances cell proliferation and increases the ER $\alpha$ content of ER-positive breast cancer cells $(30,31)$. However, the effects of zeranol on aromatase activity and estrogen production in human breast preadipocytes remain unclear.

In the present study, primary preadipocytes isolated from human breast adipose tissues were used as a cell model. The results indicated that zeranol $(2-50 \mathrm{nM})$ increased proliferation of preadipocytes in a dose-dependent manner, as determined by an MTS assay, and this effect was blocked by the ER antagonist, ICI (Fig. 1). This result suggested that zeranol may increase cell proliferation via an effect on ER. Furthermore, the present study demonstrated that zeranol induced the upregulation of aromatase mRNA expression (Fig. 3) and aromatase activity in preadipocytes (Fig. 4). The effects on aromatase activity were abrogated by the aromatase inhibitor, letrozole. In addition, E2 production was increased following the treatment of preadipocytes with low doses of zeranol (Fig. 5). The results of the present study suggested that zeranol may promote breast cancer cell growth by stimulating aromatase activation and improving estrogen biosynthesis in the adipose tissue microenvironment.

In conclusion, the results of the present study indicated that exposure to low doses of zeranol may increase the risk of breast cancer by increasing estrogen levels in adipose tissue. Estrogen generated from preadipocytes acts as a functional signal linking adipose to epithelial tissue, and in vivo zeranol may stimulate estrogen release, thus inducing the excessive proliferation of mammary cells. However, more comprehensive studies are required to confirm these findings.

\section{Acknowledgements}

This research project was supported by grants from the National Natural Science Foundation of China (grant no. 31201424) and the Natural Science Foundation of Guangdong Province (grant no. S2012040006790), and the Science and Technology Department of Guangdong Province (grant no. 2015A020209166).

\section{References}

1. DeSantis C, Ma J, Bryan L and Jemal A: Breast cancer statistics, 2013. CA Cancer J Clin 64: 52-62, 2014.

2. Yager JD and Davidson NE: Estrogen carcinogenesis in breast cancer. N Engl J Med 354: 270-282, 2006.

3. Ciocca DR and Fanelli MA: Estrogen receptors and cell proliferation in breast cancer. Trends Endocrinol Metab 8: 313-321, 1997.

4. Boon WC, Chow JD and Simpson ER: The multiple roles of estrogens and the enzyme aromatase. Prog Brain Res 181: 209-232, 2010.

5. Liang N, Xu Y, Yin Y, Yao G, Tian H, Wang G, Lian J, Wang Y and Sun F: Steroidogenic factor-1 is required for TGF-beta3-mediated 17beta-estradiol synthesis in mouse ovarian granulosa cells. Endocrinology 152: 3213-3225, 2011.

6. Simpson ER, Michael MD, Agarwal VR, Hinshelwood MM, Bulun SE and Zhao Y: Cytochromes P450 11: Expression of the CYP19 (aromatase) gene: An unusual case of alternative promoter usage. FASEB J 11: 29-36, 1997.
7. Kamat A, Hinshelwood MM, Murry BA and Mendelson CR: Mechanisms in tissue-specific regulation of estrogen biosynthesis in humans. Trends Endocrin Metab 13: 122-128, 2002.

8. Campbell DR and Kurzer MS: Flavonoid inhibition of aromatase enzyme activity in human preadipocytes. J Steroid Biochem Mol Biol 46: 381-388, 1993.

9. Bulun SE, Lin Z, Imir G, Amin S, Demura M, Yilmaz B, Martin R, Utsunomiya $\mathrm{H}$, Thung S, Gurates B, et al: Regulation of aromatase expression in estrogen-responsive breast and uterine disease: From bench to treatment. Pharmacol Rev 57: 359-383, 2005.

10. Lorincz AM and Sukumar S: Molecular links between obesity and breast cancer. Endocr Relat Cancer 13: 279-292, 2006.

11. Dirat B, Bochet L, Dabek M, Daviaud D, Dauvillier S, Majed B, Wang YY, Meulle A, Salles B, Le Gonidec S, et al: Cancer-associated adipocytes exhibit an activated phenotype and contribute to breast cancer invasion. Cancer Res 71: 2455-2465, 2011.

12. Arase S, Ishii K, Igarashi K, Aisaki K, Yoshio Y, Matsushima A, Shimohigashi Y, Arima K, Kanno J and Sugimura Y: Endocrine disrupter bisphenol A increases in situ estrogen production in the mouse urogenital sinus. Biolo Reprod 84: 734-742, 2011.

13. Manna PR, Dyson MT and Stocco DM: Regulation of the steroidogenic acute regulatory protein gene expression: Present and future perspectives. Mol Hum Reprod 15: 321-333, 2009.

14. Zhong S, Ye W, Lin SH, Liu JY, Leong J, Ma C and Lin YC: Zeranol induces cell proliferation and protein disulfide isomerase expression in mammary gland of ACI rat. Anticancer Res 31: 1659-1665, 2011.

15. Zhong S, Ye WP, Feng E, Lin SH, Liu JY, Leong J, Ma C and Lin YC: Serum derived from zeranol-implanted ACI rats promotes the growth of human breast cancer cells in vitro. Anticancer Res 31: 481-486, 2011.

16. Updike MS, Sawdy JC, Wang LS, Liu S, Huang YW, Ye W, Farrar WB, Lin YC and Wick M: Primary cultured human breast epithelial cells up-regulate protein disulfide isomerase in response to zeranol. Anticancer Res 27: 407-410, 2007.

17. Liu S and Lin YC: Transformation of MCF-10A human breast epithelial cells by zeranol and estradiol-17beta. Breast J 10: 514-521, 2004

18. Ye W, Xu P, Threlfall WR, Jen R, Li H, Lin SH, Kuo CT and Lin YC: Zeranol enhances the proliferation of preadipocytes in beef heifers. Anticancer Res 29: 5045-5052, 2009.

19. Zhong S, Ye W, Xu PP, Feng E, Li H, Lin SH, Liu JY, Ma C and Lin YC: Aromatase expression in leptin-pretreated human breast preadipocytes is enhanced by zeranol and suppressed by (-)-gossypol. Anticancer Res 30: 5077-5084, 2010.

20. Lephart ED and Simpson ER: Assay of aromatase activity. Methods Enzymol 206: 477-483, 1991.

21. Tennant JR: Evaluation of the trypan blue technique for determination of cell viability. Transplantation 2: 685-694, 1964.

22. Russo J and Russo IH: The role of estrogen in the initiation of breast cancer. J Steroid Biochem Mol Biol 102: 89-96, 2006.

23. Smith IE and Dowsett M: Aromatase inhibitors in breast cancer. New Engl J Med 348: 2431-2442, 2003.

24. Utsumi T, Harada N, Maruta M and Takagi Y: Presence of alternatively spliced transcripts of aromatase gene in human breast cancer. J Clin Endocrinol Metab 81: 2344-2349, 1996.

25. Brodie A, Lu Q and Nakamura J: Aromatase in the normal breast and breast cancer. J Steroid Biochem Mol Biol 61: 281-286, 1997.

26. Blankenstein MA, van de Ven J, Maitimu-Smeele I, Donker GH, de Jong PC, Daroszewski J, Szymczak J, Milewicz A and Thijssen JH: Intratumoural levels of estrogens in breast cancer. J Steroid Biochem Mol Biol 69: 293-297, 1999.

27. Sanderson JT, Seinen W, Giesy JP and van den Berg M: 2-Chloro-s-triazine herbicides induce aromatase (CYP19) activity in H295R human adrenocortical carcinoma cells: A novel mechanism for estrogenicity? Toxicol Sci 54: 121-127, 2000.

28. Morinaga H, Yanase T, Nomura M, Okabe T, Goto K, Harada N and Nawata $\mathrm{H}$ : A benzimidazole fungicide, benomyl, and its metabolite, carbendazim, induce aromatase activity in a human ovarian granulose-like tumor cell line (KGN). Endocrinology 145: 1860-1869, 2004.

29. Thibaut R and Porte C: Effects of endocrine disrupters on sex steroid synthesis and metabolism pathways in fish. J Steroid Biochem Mol Biol 92: 485-494, 2004.

30. Xu P, Ye W, Li H, Lin SH, Kuo CT, Feng E and Lin YC: Zeranol enhances leptin-induced proliferation in primary cultured human breast cancer epithelial cells. Mol Med Rep 3: 795-800, 2010.

31. Takemura H, Shim JY, Sayama K, Tsubura A, Zhu BT and Shimoi K: Characterization of the estrogenic activities of zearalenone and zeranol in vivo and in vitro. J Steroid Biochem Mol Biol 103: 170-177, 2007. 